\title{
Brain-Derived Neurotrophic Factor Promotes the Differentiation of Various Hippocampal Nonpyramidal Neurons, Including Cajal-Retzius Cells, in Organotypic Slice Cultures
}

\author{
Serge Marty, ${ }^{1}$ Patrick Carroll,, ${ }^{1}$ Alessandro Cellerino, ${ }^{2}$ Eero Castrén, ${ }^{1}$ Volker Staiger, ${ }^{3}$ Hans Thoenen, ${ }^{1}$ and \\ Dan Lindholm ${ }^{1}$
}

Departments of ${ }^{1}$ Neurochemistry, ${ }^{2}$ Neurobiochemistry, and ${ }^{3}$ Neurophysiology, Max Planck Institute for Psychiatry, D-82152 Martinsried, Germany

\begin{abstract}
Brain-derived neurotrophic factor (BDNF) is widely expressed in the central nervous system, where its function is poorly understood. The aim of this study was to investigate the effects of BDNF on the differentiation of hippocampal nonpyramidal neurons using organotypic slice cultures prepared from postnatal rats.

The application of BDNF induced an increase in immunostaining for the microtubule-associated protein (MAP)-2 in nonpyramidal neurons of the stratum oriens. BDNF promotes the elongation of the dendrites of these neurons, as demonstrated by analysis after biocytin labeling. Calbindin-D- and calretinincontaining subgroups of nonpyramidal cells in the stratum oriens were responsive to BDNF but not to nerve growth factor, as shown by an increase in the number of neurons immunostained for these proteins. BDNF also induced an increase in neuropeptide $Y$ immunostaining of stratum oriens neurons. In
\end{abstract}

contrast, BDNF had no effect on parvalbumin immunostaining, despite the fact that these cells express the BDNF receptor trkB. In addition, BDNF increased calretinin immunoreactivity in Cajal-Retzius cells situated around the hippocampal fissure. The Cajal-Retzius neurons persisted in slices beyond the time at which they degenerate in vivo. However, BDNF is not required for the survival of these cells, because they also persisted in slices from BDNF knock-out mice.

The present results indicate that BDNF exerts an effect on the morphology of stratum oriens nonpyramidal cells and their calcium-binding protein levels. BDNF also regulates the calretinin content of Cajal-Retzius cells but is not necessary for their survival.

Key words: MAP-2; calbindin-D; parvalbumin; calretinin; neuropeptide $Y$; neurotrophins; development; rat
Brain-derived neurotrophic factor (BDNF) is a member of the neurotrophin gene family (Barde, 1990; Lindsay, 1993; Götz et al., 1994; Snider, 1994), which has been shown to play a critical role in the survival and differentiation of neurons in the peripheral nervous system (Davies, 1994). BDNF is widely expressed in the central nervous system, with the highest levels of mRNA being found in the hippocampus (Hofer et al., 1990). Nevertheless, the function of BDNF in the hippocampus remains unclear.

Data obtained from in vitro studies indicated that BDNF stimulates signal transduction pathways, induces c-fos, and increases the number of calbindin-immunoreactive cells in cultures of dissociated hippocampal neurons (Collazo et al., 1992; Ip et al., 1993; Marsh et al., 1993; Oshawa et al., 1993). However, the identity of hippocampal neurons that respond to BDNF has not been determined.

Studies of BDNF knock-out mice showed no alterations in hippocampal morphology, but a decrease in immunoreactivity for calbindin, parvalbumin, and neuropeptide $Y$ in interneurons was observed (Jones et al., 1994). Although the data are difficult to interpret because of the delay in maturation and the early death of

Received June 9, 1995; revised Oct. 4, 1995; accepted Oct. 11, 1995.

S.M. was supported by a grant from the Institut National de la Santé et de la Recherche Médicale. We thank Benedikt Berninger and Dr. Jonathan Cooper for critical review of the manuscript.

Correspondence should be addressed to Serge Marty, Department of Neurochemistry, Max Planck Institute for Psychiatry, Am Klopferspitz 18A, D-82.152. Martinsried, Germany.

Copyright $(1996$ Society for Neuroscience $\quad 0270-6474 / 96 / 160675-13 \$ 05.00 / 0$ the BDNF knock-out mice, they point to a possible involvement of BDNF in the differentiation of hippocampal nonpyramidal neurons. Indeed, the responsiveness of these cells to BDNF has been shown in vivo by an increase in their neuropeptide content (Croll et al., 1994; Nawa et al., 1994).

The aim of this study was to investigate the effects of BDNF on the differentiation of hippocampal nonpyramidal cells by using organotypic slice cultures, which permit a more controlled stimulation of neurons with BDNF than in vivo and, in contrast to dissociated cell cultures, an identification of the neuronal types on the basis of their location and morphology.

We first aimed to determine whether BDNF could affect the morphology of nonpyramidal neurons in cultured hippocampal slices prepared from 8-d-old rats. We investigated the effects of BDNF on the immunostaining of microtubule-associated protein (MAP)-2 and on the dendritic arborizations of these cells by labeling with biocytin (McDonald, 1992).

Second, we studied whether the different subgroups of nonpyramidal neurons are sensitive to BDNF. The calcium-binding proteins are good markers for these subgroups of neurons (Gulyás et al., 1992; Miettinen et al., 1992; Rogers and Résibois, 1992). We analyzed the effects of BDNF on calbindin-D-, calretinin-, and parvalbumin-positive neurons. In addition, calretinin immunostaining labels a transient population of cells equivalent to the Cajal-Retzius cells of the cerebral cortex (Del Río et al., 1995). Using slices from BDNF knock-out mice, we studied the effect of BDNF treatment on these neurons and the possible involvement of BDNF in their survival. 
Finally, because BDNF has been shown recently to enhance the transmitter release from hippocampal neurons (Lessmann et al., 1994; Berzaghi et al., 1995; Kang and Schuman, 1995), we investigated whether the effects of BDNF on nonpyramidal neurons could be indirect, via an influence on neuronal activity.

\section{MATERIALS AND METHODS}

Eight-day-old Wistar rats or BDNF knock-out mice were used in this study. It was not possible to detect parvalbumin-containing neurons in slices from 8 -d-old rats. This is probably attributable to the rather late appearance of parvalbumin postnatally (Nitsch et al., 1990; Bergmann et al., 1991). For this reason, parvalbumin immunostaining was performed in slices taken from 10 -d-old rats.

Mutation at the BDNF locus was generated by homologous recombination. In the gene-largeting construcl, a 560 bp ApaI fragment from the BDNF protein-coding exon was replaced by a GK-NEO-polyA selection marker, thus deleting part of the BDNF pro-region and most of the sequence coding for the mature BINNF protein. Mice carrying the disrupted BDNF gene were generated by homologous recombination in the D3 (agouti mouse strain 129/SV) ES cell line following standard methodology (Hasty and Bradley, 1993). Chimeric mice were generated by injection of mutated cells into $\mathrm{C} 57 \mathrm{BL} / 6$ (non-agouti) mice blastocysts High coat color chimeric male mice were crossed with NMRI females. Heterozygous progeny were identified by Southern blotting (Korte et al. 1995). In keeping with previously published reports (Ernfors et al., 1994; Jones et al., 1994), BDNF homologous mutant mice were retarded in growth, displayed aberrant limb coordination and balance, showed a loss of neurons in the dorsal root ganglia, and usually died between 2 and 4 weeks after birth.

Slice culture. Cultures of hippocampal slices were prepared using the method of Stoppini et al. (1991), with the exception that a defined medium was used as described below.

Wistar rats or BDNF knock-out mice were decapitated, and the brains were rapidly removed. The following procedure was performed under sterile conditions. Hippocampi were dissected in sodium phosphate buffer with $0.9 \% \mathrm{NaCl}(0.1 \mathrm{M}$ PBS, $\mathrm{pH} 7.4)$. To avoid extrahippocampal influences on the differentiation of nemrons (I a Vail and Wolf, 197.3), the hippocampi were totally isolated from adjoining cerebral cortex during the dissection procedure. Slices $(400 \mu \mathrm{m})$ were cut perpendicular to the septotemporal axis of the hippocampus with use of a McIllwain tissue chopper (Mickle Laboratory, Gomshall, UK). Hippocampal slices were then transferred into the culture medium, separated, and transferred unto Millicell-CM membranes (Millipore, Bedford, MA). A total of 12 adjacent slices were obtained per brain. Adjacent slices were transferred onto different Millicell membranes to compare the effects of the treatments with control adjacent sections.

The Millicell membranes were kept in 6-well plates above $750 \mu l$ of defined medium. The medium consisted of minimum essential medium (MEM; Gibco 11012-010, Gibco, Eggenstein, Germany), 1\% D-glucose, 5 $\mathrm{mM}$ Tris- $\mathrm{HCl}, 100 \mu \mathrm{g} / \mathrm{ml}$ bovine serum albumin, $100 \mu \mathrm{g} / \mathrm{ml}$ transferrin, 16 $\mathrm{ng} / \mathrm{ml}$ putrescine, $40 \mathrm{ng} / \mathrm{ml} N$-selenium, $30 \mathrm{ng} / \mathrm{ml}$ tri-iodothyronin, $5 \mu \mathrm{g} / \mathrm{ml}$ insulin, and $60 \mathrm{ng} / \mathrm{ml}$ progesterone (all purchased from Sigma, Deisenhofen, Germany). Slices were incubated at $37^{\circ} \mathrm{C}$ in $5 \% \mathrm{CO}_{2}$. The medium was exchanged every second day.

Stimulation of slices with neurotrophins. Recombinant human BDNF (Regeneron Pharmaceuticals, Tarrytown, NY) or $2.5 \mathrm{~S}$ nerve growth factur (NGF) extracted frum the submaxillary glands of mice (Suda et al., 1978 ) was diluted in PBS $(0.1 \mathrm{M}, \mathrm{pH} 7.4)$ containing $0.1 \%$ bovine serum albumin.

Induction of c-fos was used as a test for the efficiency of the BDNF treatment. Addition of up to $0.5 \mu \mathrm{g} / \mathrm{ml}$ BDNF to the medium under the Millicells did not induce c-fos immunostaining in slices after 2 or $3 \mathrm{hr}$ (see immunohistochemical methods below). For this reason, $1 \mu$ l of the BDNF-containing solution was applied on top of each slice, covering the entire surface. Initial experiments showed that c-fos was already induced with $20 \mathrm{ng}$ of BDNF, but the addition of $100 \mathrm{ng}$ of BDNF induced a greater intensity of c-fos immunostaining. For all subsequent experiments, $100 \mathrm{ng}$ of BDNF or NGF was applied daily. $\Lambda$ s a control, adjacent sections received $1 \mu \mathrm{l}$ of vehicle solution.

Immunohistochemistry. After fixation for $4 \mathrm{hr}$ in $4 \%$-formaldehyde in PBS, slices were rinsed several times in PBS and incubated for 30 min in PBS containing 1\% Triton $X-100$ and $3 \%$ normal goat serum (Sigma). Slices were then incubated overnight at $4^{\circ} \mathrm{C}$ with antibodies raised against c-fos (1:2000; Santa Cruz Biotechnology, Santa Cruz, CA), MAP-2 (1:200 Boehringer Mannheim, Mannheim, Germany), calbindin-D (1:200; Sigma), calretinin (1:5000; Swant, Bellinzona, Switzerland), parvalbumin (1:1000; Sigma), or neuropeptide Y $(1: 2000 ;$ Amersham, Braunschweig Germany) diluted in PBS containing $1 \%$ Triton X-100 and $1 \%$ normal goat serum. After washes in PBS, slices were incubated for 1 hr with a solution containing either anti-rabbit or anti-mouse IgG-biotinylated antisera (1:100; Vector Labs, Camon, Wiesbaden, Germany) in PBS containing $1 \%$ Triton $\mathrm{X}-100$ and $1 \%$ normal goat serum. After several washes in PBS, slices were incubated for $1 \mathrm{hr}$ with an avidin-biotinhorseradish peroxidase complex $(1: 100$; Vector) in PBS containing $1 \%$ Iriton $X$-100. Staining was developed with a PBS solution containing $0.05 \%$ diaminobenzidine (Sigma) and $0.01 \%$ hydrogen peroxide. Slices were rinsed in PBS, mounted onto gelatin-coated slides, air-dried before clearing in xylene, and coverslipped in DPX (BDH, Poole, UK) in the normal manner.

Double-labeling trkB in situ hybridization-parvalbumin immunohistochemistry. Adult Long-Evans hooded rats were anesthetized with chloral hydrate $(10.5 \%, 6-8 \mathrm{ml} / \mathrm{kg})$ and perfused through the ascending aorta willı $0.9 \%$ NaCl at roon temperature (RT) followed by $4 \%$ $p$-formaldehyde in PBS (RT). The brains were postfixed for $2-4 \mathrm{hr}$ in the same fixative and cryoprotected in $30 \%$ sucrose in PBS overnight. Thirty micrometer sections were cut with a cryostat (Leitz, Leica, Munich, Germany), collected in RNase-free PBS, and stored at $4^{\circ} \mathrm{C}$ for a maximum of $24 \mathrm{hr}$.

The probe was prepared using DNA polymerase ( $\mathrm{T} 7$ for the antisense probe and T3 for the sense probe) and $1 \mu \mathrm{g}$ of template DNA in $25 \mu \mathrm{l}$ of transcription buffer containing $1 \mu \mathrm{l}$ of RNase inhibitor, $40 \mathrm{~mm}$ dithiothreitol (DTT), $4 \mathrm{~mm}$ CTP, $4 \mathrm{~mm}$ GTP, $4 \mathrm{mM} \mathrm{ATP}$, and $100 \mu \mathrm{Ci}$ of ${ }^{35}$ S-labeled UTP (Amersham). The riboprobe (a kind gift of Dr. Nina Offenhäuser) was obtained by polymerase chain reaction amplification of rat brain cDNA, which corresponded to nucleotides $19-412$ of the rat trkB. The transcription was terminated by adding $75 \mu \mathrm{l}$ of $100 \mathrm{~mm}$ DTT, $25 \mu \mathrm{g}$ of Escherichia coli $\mathrm{tRNA}$, and $6 \mathrm{U}$ of DNase at $37^{\circ} \mathrm{C}$ for $15 \mathrm{~min}$. The probe was separated from the unincorporated nucleotides by adding 50 $\mathrm{ml}$ of $7.5 \mathrm{M}$ ammonium acetate and $375 \mathrm{ml}$ of $100 \%$ ethanol for $1 \mathrm{hr}$ at $-80^{\circ} \mathrm{C}$. The RNA was precipitated, centrifuged, resuspended in $100 \mathrm{ml}$ of $100 \mathrm{~mm}$ DTT, and stored at $-80^{\circ} \mathrm{C}$. The incorporation efficiency was usually $-90 \%$, as assessed on a beta counter.

Selected sections were transferred in Costar microsieves fitted into 12 well sterile culture plates and incubated as follows: $4 \% p$-formaldehyde for $5 \mathrm{~min}$; PBS for $5 \mathrm{~min}$; $0.6 \mathrm{mg} / \mathrm{ml}$ proteinase $\mathrm{K}$ (Boehringer) in $50 \mathrm{~mm}$ Tris, pH 7.5, 5 mM EDTA, pH 7.5, for $15 \mathrm{~min}$; proteinase buffer for $5 \mathrm{~min}$; and $0.25 \%$ acetic anhydride in $0.1 \mathrm{~m}$ tricthanol amine, $\mathrm{pH} 8$, for $10 \mathrm{~min}$. All of the passages were performed at RT under gentle agitation. Sections were kept in PBS until prehybridized in $50 \%$ formamide, $0.3 \mathrm{M}$ $\mathrm{NaCl}, 20 \mathrm{~mm}$ Tris, $\mathrm{pH} 8,5 \mathrm{~mm}$ FDTA, $10 \%$ dextran sulfate, $1 \times$ Denhardt's solution, $0.5 \mathrm{mg} / \mathrm{ml}$ tRNA, and $20 \mathrm{~mm}$ DTT at $60^{\circ} \mathrm{C}$ for $2 \mathrm{hr}$. Sections were then transferred with a fine glass hook into a fresh 12 -well culturc dish containing $500 \mathrm{ml}$ of fresh prchybridization solution preheated at $60^{\circ} \mathrm{C}$, which contained $5,000,000 \mathrm{cpm} / \mathrm{ml}$ labeled probe, and were incubated overnight at $60^{\circ} \mathrm{C}$ with gentle agitation. The following washes were then performed: $5 \times \mathrm{SSC}, 10 \mathrm{~mm}$ DTT at $55^{\circ} \mathrm{C}$ for $5 \mathrm{~min}$; $50 \%$ formamide, $2 \times \mathrm{SSC}, 20 \mathrm{~mm} \mathrm{DTT}$ at $65^{\circ} \mathrm{C}$ for $20 \mathrm{~min} ; 0.5 \mathrm{M} \mathrm{NaCl}, 10$ mM Tris, pH 8, $5 \mathrm{~mm}$ EDTA at $37^{\circ} \mathrm{C}$ three times for $10 \mathrm{~min} ; 12.5 \mathrm{mg} / \mathrm{ml}$ RNase A (Boehringer) in $0.5 \mathrm{M} \mathrm{NaCl}, 10 \mathrm{mM}$ Tris, pH $8,5 \mathrm{mM}$ EDTA at $37^{\circ} \mathrm{C}$ for $30 \mathrm{~min} ; 0.5 \mathrm{M} \mathrm{NaCl}, 10 \mathrm{~mm}$ Tris, $\mathrm{pH} 8,5 \mathrm{~mm}$ EDTA at $37^{\circ} \mathrm{C}$ for $10 \mathrm{~min} ; 50 \%$ formamide, $2 \times \mathrm{SSC}, 20 \mathrm{~mm} \mathrm{DTT}$ at $65^{\circ} \mathrm{C}$ for $20 \mathrm{~min} ; 2 \times$ SSC for 10 min at RT; and $0.1 \times$ SSC for $1 \mathrm{hr}$ at RT.

Sections were blocked in $30 \%$ normal horse serum (NHS) in PBS for 1-2 hr at RT and subsequently reacted with monoclonal antiparvalbumin (Sigma) at a concentration of $0.3 \mu \mathrm{g} / \mathrm{ml}$ in $30 \%$ NHS and $0.03 \%$ Triton $\mathrm{X}-100$ in PBS overnight at $4^{\circ} \mathrm{C}$. Sections were washed three times in PBS and then processed according to the Vector Vectastain protocol. The immunoreactivity was revealed by incubating the sections in $1 \mathrm{mg} / \mathrm{ml}$ DAB (Sigma) in PBS with $0.008 \%$ ammonium chloride, $0.4 \%$ glucose, and $0.3 \mathrm{mg} / \mathrm{ml}$ glucose oxidase solution (Sigma G-6891) for $30 \mathrm{~min}$ at RT. Sections were mounted onto gelatin-coated slides, air-dried overnight, dehydrated in ascending alcohol containing $0.3 \%$ ammonium acetate, air-dried, dipped in Kodak NBT2 emulsion (Kodak, Siemens, Munich, Germany) diluted $1: 1$ with $0.6 \mathrm{M}$ ammonium acetate, and developed after 2,4 , and 6 weeks with D19 developer (Kodak) for 4 min at RT, blocked in $1 \%$ acetic acid ( $30 \mathrm{sec}$ ), and fixed in Unifix (Kodak) ( $8 \mathrm{~min}$ ). Slides were air-dried, dehydrated through ascending alcohols, cleared in xylene, 
and coverslipped with mounting medium (Permount, Fisher, Kühn and Bayer, Nidderan, Germany).

Biocytin labeling. Crystals of biocytin (Sigma) were inserted into the stratum oriens using a glass micropipette under visual control. The slices were then left overnight in the incubator. After fixation for $4 \mathrm{hr}$ in $2 \%$ $p$-formaldehyde and $1 \%$ glutaraldehyde in PBS (0.1 M, pH 7.4), slices were washed before incubation for $4 \mathrm{hr}$ with an avidin-biotin-horseradish peroxidase complex (1:100; Vector) in PBS containing 1\% Triton $\mathrm{X}-100$. Staining was developed as for immunohistochemistry.

Quantification. After biocytin labeling, dendritic branches could be distinguished from axons because the dendrites emerge from the soma as thick processes that taper along their course. The number of dendritic branch points was directly counted under the microscope by using a $40 \times$ magnification objective. Only neurons that were sufficiently separated from each other, thus permitting their dendritic arbor to be traced clearly, were analyzed. These measurements were made in slices taken from four animals, allowing the analysis of a total of 25 neurons ( 12 control neurons and 13 BDNF-treated neurons, with a minimum of 3 neurons analyzed/ animal on control slices and on adjacent treated slices). The number of primary dendrites also was directly counted under the microscope by using a $40 \times$ magnification objective. These measurements were made in slices taken from four animals, allowing the analysis of a total of 110 neurons (51 control neurons and 59 BDNF-treated neurons). It was not possible to analyze the total dendritic length of these neurons because of the frequent overlap of short dendrites from different neurons, particularly in the vicinity of the injection site. We focused our analysis, therefore, on the longest dendritic branch per neuron, which was usually easy to follow to its distal end. To measure the extent of the longest dendritic branch per neuron, a ruler was superimposed on the slices by using a camera lucida drawing tube. The length from the point of emergence of the dendrite to its tip was measured. These measurements were made in slices taken from four animals, allowing the analysis of a total of 78 neurons ( 32 control neurons and 46 BDNF-treated neurons). The mean of the values per animal was calculated. The mean of these four values is presented together with the SEM and the results of unpaired Student's $t$ test analysis.

After calbindin-D immunohistochemistry, the density of immunopositive cells in the stratum oriens was determined. Counts were performed in a $7225-\mu \mathrm{m}^{2}$-area square using $20 \times$ magnification lenses. The square was displaced on the stratum oriens from a random starting point, and counts were performed every half visual field, thus allowing three measurements per slice. After calretinin or parvalbumin immunohistochemistry, the total number of immunopositive cells in the stratum oriens or pyramidal cell layer, respectively, was determined. These measurements were performed in slices taken from four animals, with three control and three adjacent treated slices analyzed per animal. Similarly, after calretinin immunohistochemistry, the total number of calretinin-immunopositive Cajal-Retzius cells surrounding the hippocampal fissure was determined. The mean of the values obtained per animal was calculated. Student's $t$ test was used for analysis as detailed above.

Tetrodotoxin treatment and electrophysiological recordings. To block neuronal activity in the slices, hippocampi were transferred into medium containing $1 \mu \mathrm{M}$ tetrodotoxin (Sigma) immediately after the slices were cut. Tetrodotoxin $(1 \mu \mathrm{M})$ was added to the slice medium in the six-well plates and to the solutions used to stimulate the slices. The efficiency of this treatment was tested after $4 \mathrm{~d}$ in culture.

Extracellular recordings were performed at a temperature of $28^{\circ} \mathrm{C}$. A monopolar tungsten electrode was used for stimulation. It was placed in the CA3 Schaffer collateral region. Stimulus intensity ranged from 50 to $150 \mu \mathrm{A}$. Responses were recorded with low-resistance glass electrodes (5-15 $\mathrm{M} \Omega$ ) filled with $3 \mathrm{M} \mathrm{NaCl}$. The electrodes were placed in the apical dendritic region (stratum radiatum) of the CA1 pyramidal neurons. Recordings were performed with an Axoclamp-2A amplifier (Axon Instruments, Foster City, CA), filtered with $1 \mathrm{kHz}$, sampled with $2 \mathrm{kHz}$, and collected with a data acquisition program written in LabView (National Instruments, Munich, Germany).

\section{RESULTS}

The slices retained their organotypic organization during the entire observation period of this study (from 2 to $14 \mathrm{~d}$ after explantation). The layers of dentate granule cells and pyramidal cells were recognizable and retained their spatial relationship. However, the infrapyramidal blade of the dentate gyrus

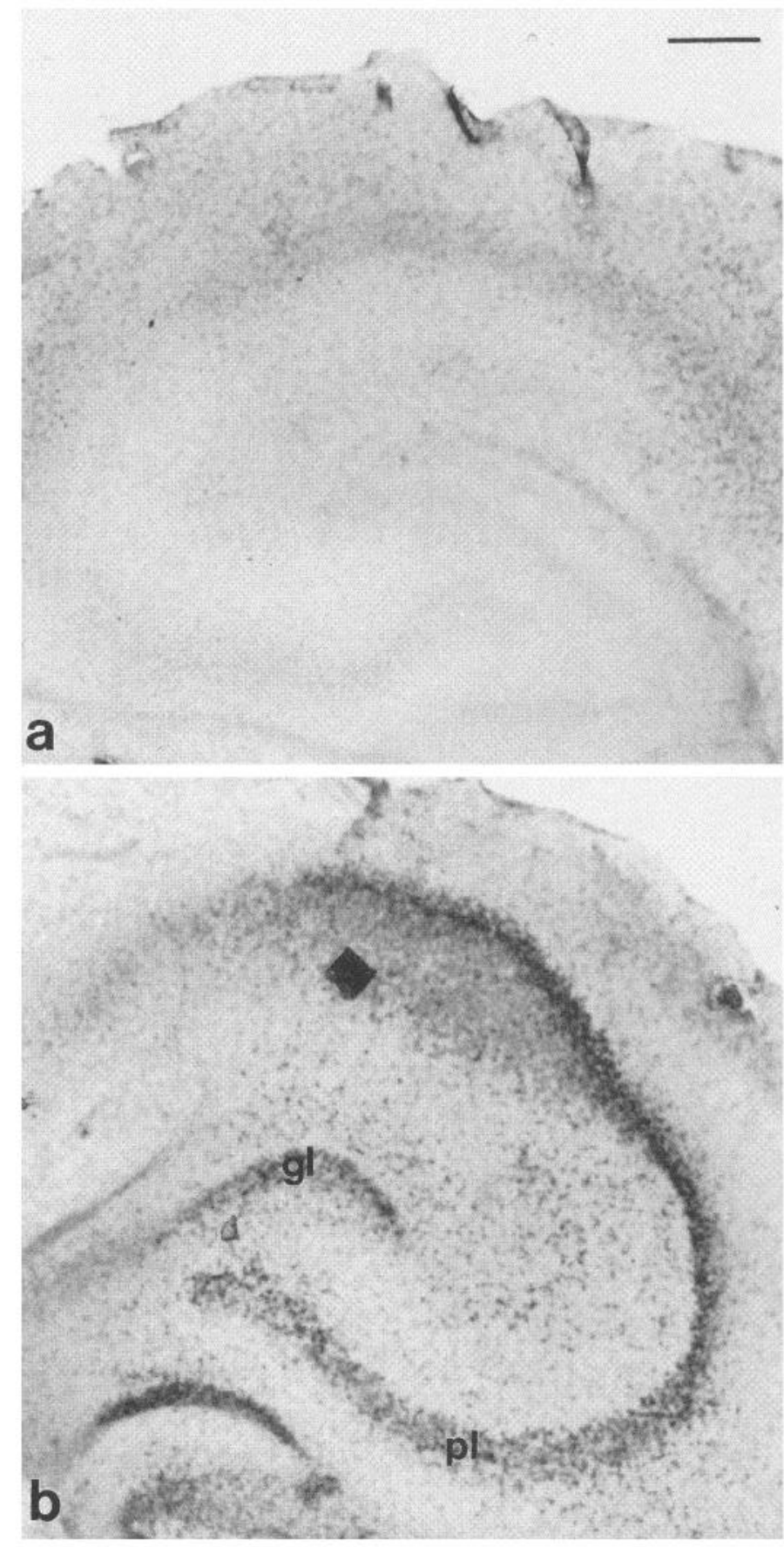

Figure 1. c-fos immunostaining of hippocampal slices $2 \mathrm{~d}$ after explantation. $a$, Control slice. $b$, Three hours after BDNF application. Note the intense c-fos immunostaining in the granule cell layer $(g l)$ and in the pyramidal cell layer $(p l)$ after BDNF treatment. Scale bar, $200 \mu \mathrm{m}$.

(which is generated later) spread, so it was not possible to identify it as a distinct cell layer. After $2 \mathrm{~d}$ in culture, flattening of the slices became apparent; this process continued during the following days, resulting in a broadening of the cell layers mentioned above. Four days after explantation, thinning of the slices permitted good staining of the neurons, and slices were thick enough to allow numerous cells to be analyzed. No major difference was observed between control and BDNF-treated 

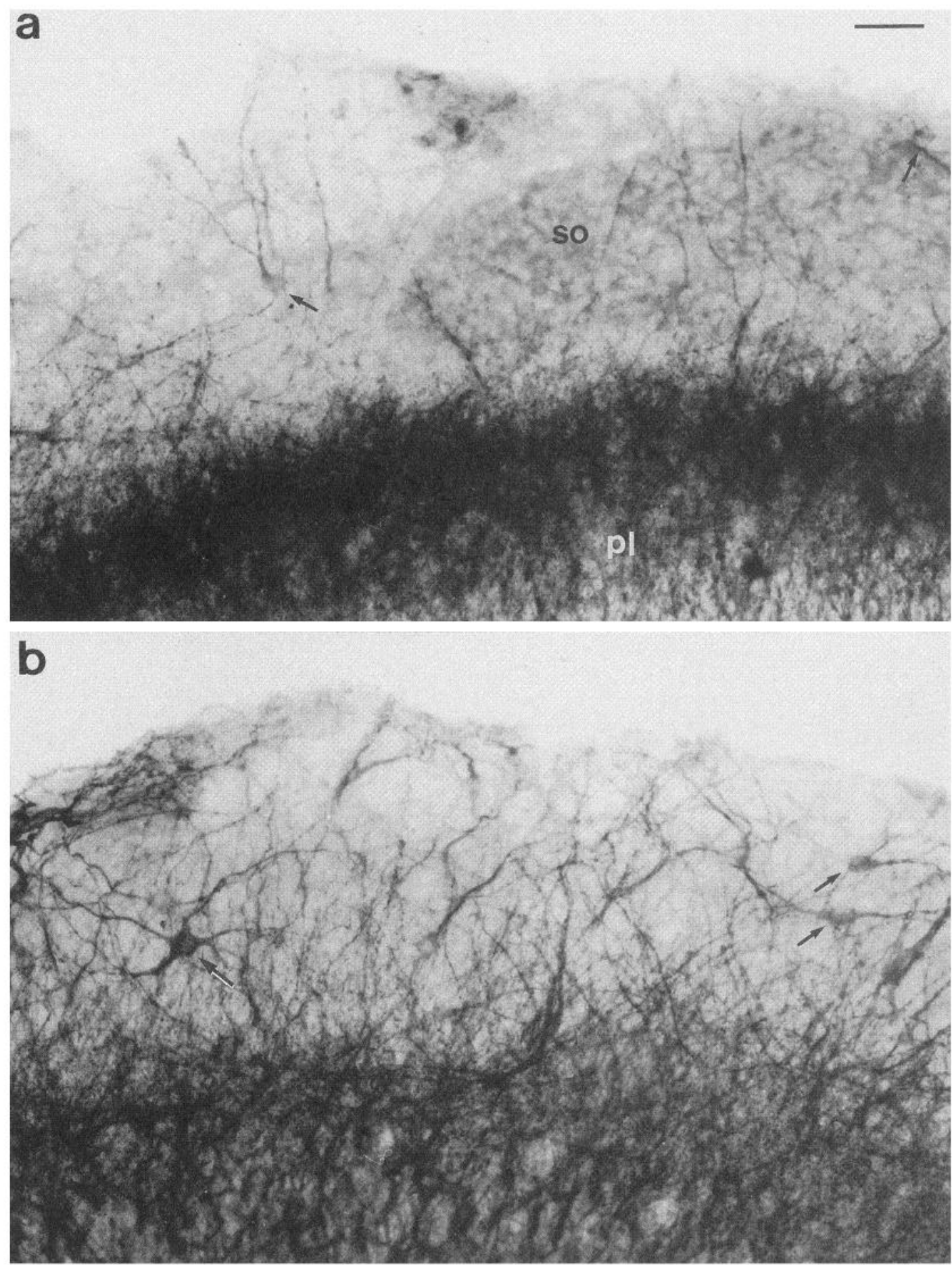

Figure 2. MAP-2 immunostaining of hippocampal slices $4 \mathrm{~d}$ after explantation. $a$, Control slice. $b$, BDNF-treated slice. Note the increase in the number of labeled cell bodies (arrows) and processes in the stratum oriens (so) after BDNF treatment. The MAP-2 immunostaining sometimes gave rise to background staining in the stratum oriens $(a)$; however, it was not systematically associated with either control or BDNF-treated slices. $p l$, Pyramidal cell layer. Scale bar, $50 \mu \mathrm{m}$.

slices with respect to either the size of the slices or their configuration.

\section{Induction of c-fos by BDNF}

BDNF (see Materials and Methods) was applied 2, 3, or $4 \mathrm{~d}$ after preparation of the slices. Two hours after BDNF application, c-fos immunoreactivity was induced in the granule cell layer of the dentate gyrus and throughout the pyramidal cell layer (Fig. 1). The labeling in these cell layers was very dense. Immunostaining was also observed outside of these layers of densely packed cells. In this latter case, it was difficult to evaluate the potential causal relationship of the labeling and the application of BDNF because scattered c-fos immunostaining was also observed on control sections. 

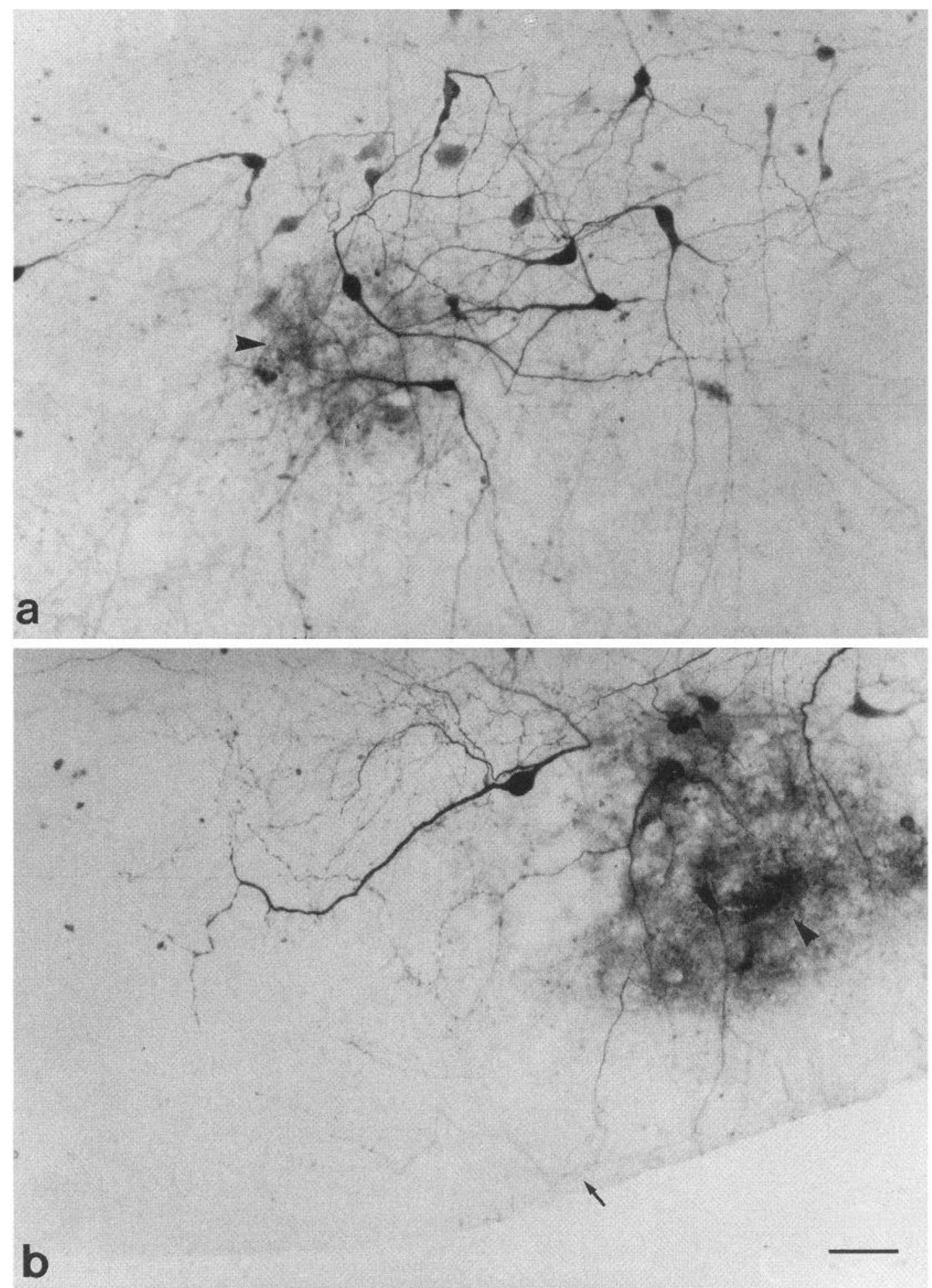

Figure 3. Biocytin labeling of hippocampal slices $4 \mathrm{~d}$ after explantation. $a$, Control. $b$, BDNF-treated. The arrowheads indicate the traces of the crystals of biocytin. $b$, Note the curved trajectory of dendrites at the border of the slice after BDNF treatment (arrow). Scale bar, $50 \mu \mathrm{m}$.

\section{Dendritic alterations after BDNF treatment}

Immunohistochemistry for MAP-2 resulted in an intense staining throughout the slices, precluding the analysis of individual cells. However, at the border of the slices, in the stratum oriens, individual cells or processes were distinguishable.

After $4 \mathrm{~d}$ in culture on control slices, a strong MAP-2 immunostaining was observed at the level of the basal dendrites of pyramidal cells (Fig. 2a). In the stratum oriens, few cell bodies and dendrites were immunostained for MAP-2. After $4 \mathrm{~d}$ of BDNF treatment (see Materials and Methods), a strong increase in immunostaining was observed in the stratum oriens (Fig. $2 b$ ). Quantitatively more cell bodies were labeled, and the cells were labeled more intensely than in the control slices. A striking increase in the number of labeled dendrites was also observed, 
a

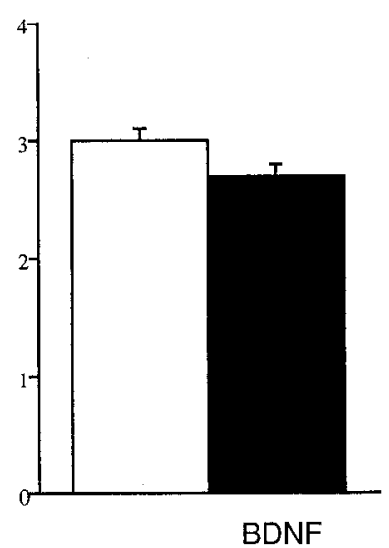

b

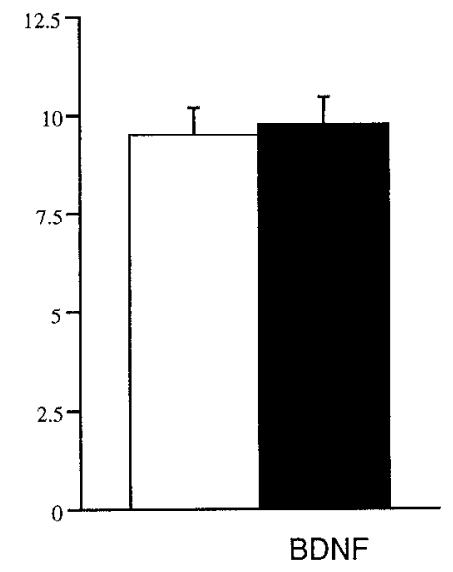

C

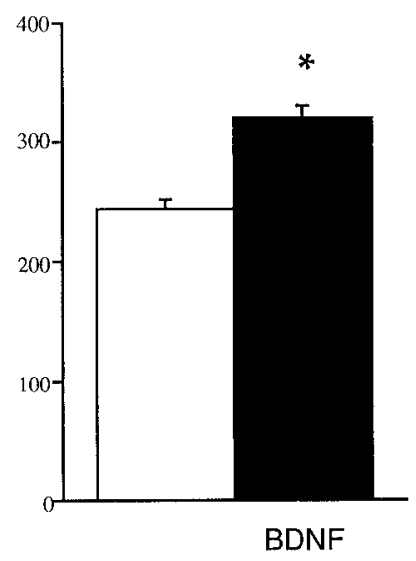

Figure 4. Quantitative analysis of biocytin-labeled cells in the stratum oriens of hippocampal slices $4 \mathrm{~d}$ after explantation. White columns represent the values obtained in control slices, and hlack columns represent the values obtained in adjacent slices treated with BDNF. a, Mean number of primary dendrites. $b$, Mean number of dendritic branch points. $c$, Mean extent of the longest dendritic branch per neuron (in $\mu \mathrm{m}$ ). Student's $t$ test indicates a significant increase in the extent of the longest dendritic branch per neuron after BDNF treatment $(p<0.05)$.

although the origin of most of those dendrites could not be determined.

Biocytin-labeled neurons were studied in slices after $4 \mathrm{~d}$ in culture, which allowed a good visualization of neuronal morphology in the stratum oriens (Fig. 3). The shape of the cell bodies varied greatly: round, elongated, pyramidal, or multipolar, sometimes crenelated, somata. From these cell bodies, a variable number of primary dendrites emerged from 2 to 6 for the 110 neurons analyzed. These dendrites were smooth, tapering along their course. Sometimes growth cone-like enlargements were observed at the tip of dendrites, either in control or in BDNF-treated slices. After $4 \mathrm{~d}$ of BDNF treatment, neurons seemed to have longer dendrites than those observed in the control slices. These dendrites sometimes exhibited a curved trajectory at the border of the slice (Fig. 3b).

Morphometric analysis indicated that BDNF treatment influenced neither the number of primary dendrites nor the number of branching points when compared with control slices (Fig. 4). However, a significant increase in the extent of the longest dendritic branch per neuron was observed.

\section{Effects of BDNF on calcium-binding proteins and neuropeptide $\mathrm{Y}$ immunostaining}

Calbindin-D, calretinin, parvalbumin, and neuropeptide $\mathrm{Y}$ immunostaining were studied in the stratum oriens and pyramidal cell layer. Delineation of the borders of the stratum oriens and pyramidal cell layer was possible because of the low background after immunostaining in the pyramidal cell layer (Fig. 5). The increase in the staining intensity of cells after treatment with BDNF was more pronounced after $4 \mathrm{~d}$ than after $2 \mathrm{~d}$; therefore, we focused our analysis on slices kept for $4 \mathrm{~d}$ in culture.

Immunohistochemistry for calbindin-D allowed staining of numerous cells scattered throughout the stratum oriens (Fig. $5 A$ ). The intensity of labeling of these cells varied greatly, from a cellular labeling that was difficult to distinguish from background to a distinct staining of cells that exhibited one or two labeled processes. BDNF-treated slices exhibited a pronounced increase in the number of labeled cells when compared with adjacent control slices. The density of labeled cells increased by $\sim 65 \%$, an effect not observed after NGF treatment (Fig. $6 a$ ). In addition, the cells were stained much more intensely than in control slices, with an increased intensity of immunostaining within their cell body and with up to four or five labeled processes (Fig. 5,4).

Calretinin-positive cells were also observed throughout the stratum oriens, although these neurons were less numerous than calbindin-immunostained cells (Fig. 5B). The staining varied greatly in intensity, from faint labeling of the cell bodies just distinguishable above background staining to cells with long stained processes. After $4 \mathrm{~d}$ of BDNF treatment, a strong increase in the number of labeled cells was observed when compared with adjacent control slices. When quantified, the increase in the number of labeled cells was found to be $\sim 60 \%$, an increase that was not observed after NGF treatment (Fig. 6b). However, it was difficult to evaluate whether BDNF treatment resulted in an increase in staining intensity of cells in the stratum oriens after BDNF treatment because some cells in control slices were labeled intensely (Fig. 5B).

At 8 and $14 \mathrm{~d}$ after explantation, a strong decrease in the number of cells immunostained for calretinin in the stratum oriens was observed on control slices (Fig. 6c). BDNF applied between 4 and $8 \mathrm{~d}$ after explantation did not prevent the decrease in the number of labeled cells (Fig. $6 c$ ).

Parvalbumin-positive cells were observed mainly within the pyramidal cell layer, although a few labeled cells were found in the stratum oriens. The intensity of labeling of these cells varied from cell bodies that were difficult to distinguish from background to cell bodies that exhibited up to five faintly labeled processes. After $4 \mathrm{~d}$ of BDNF treatment, no increase in either the number of positive cells or the intensity of staining was observed (data not shown). Quantification indicated no increase in the number of labeled cells in the pyramidal cell layer (mean \pm SEM: $76 \pm 4$ in control slices, $74 \pm 4$ in BDNF-treated slices). The effects of BDNF on parvalbumin immunostaining were tested on slices from 10-d-old rats, whereas the effects of BDNF on the other markers were tested on slices from 8-d-old rats (see Materials and Methods). We therefore tested whether BDNF was as efficient in increasing calretinin (see above) or neuropeptide $\mathrm{Y}$ (see below) immunoreactivity in slices from 10 -d-old rats as it was in slices from 8-d-old rats. By comparing three control slices with three adjacent BDNF-treated slices for each marker, we found that, 

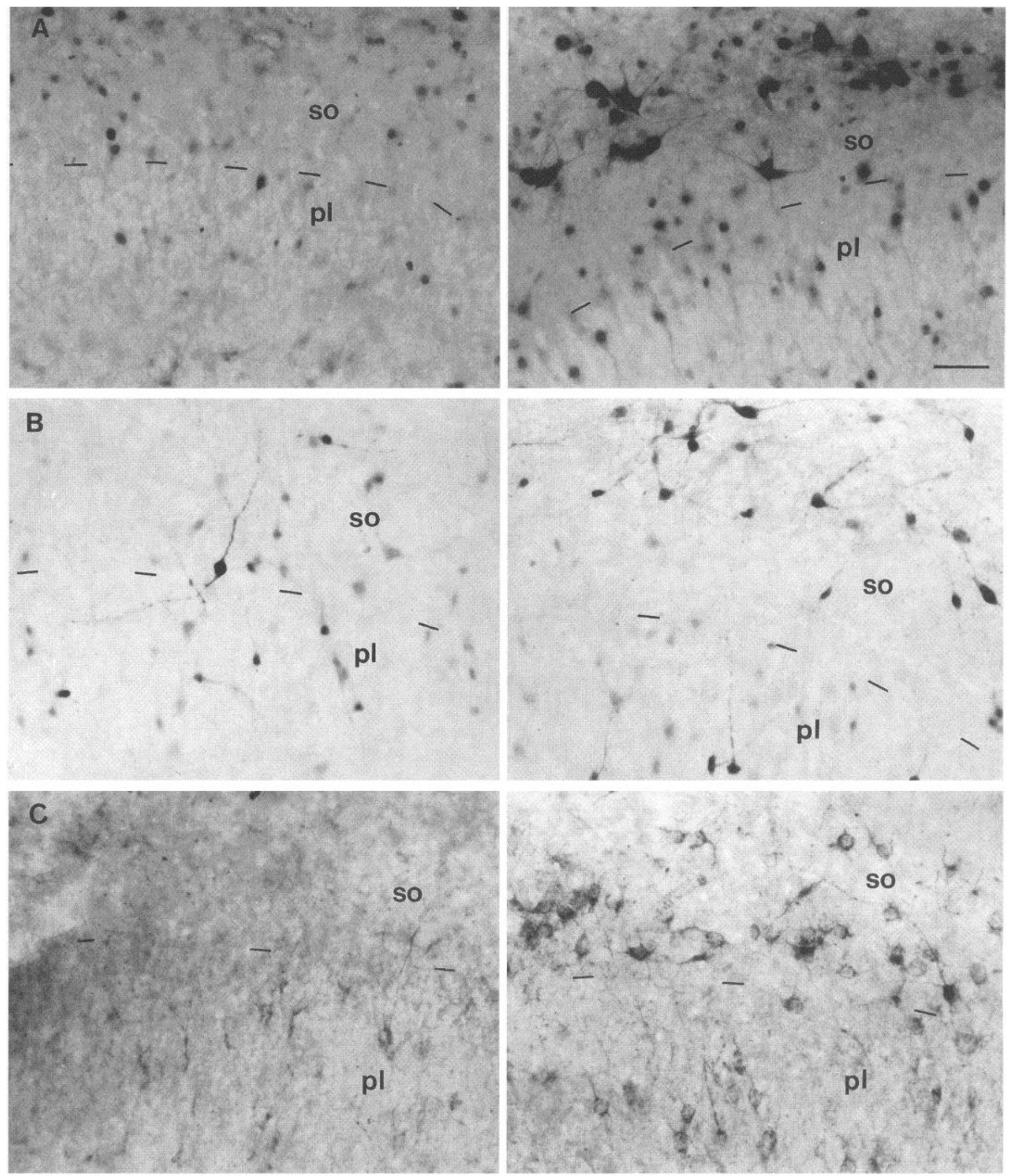

Figure 5. Immunostaining of hippocampal slices $4 \mathrm{~d}$ after explantation. Left, Control slices. Right, BDNF-treated slices. The dashed lines indicate the border between the stratum oriens (so) and the pyramidal cell layer $(p l)$. $A$, Calbindin-D immunostaining. Note the increased immunostaining of cells in the stratum oriens after BDNF treatment. $B$, Calretinin immunostaining. Note the increase in the number of cells immunostained for calretinin in the stratum oriens after BDNF treatment. $C$, Neuropeptide Y immunostaining. Note the increase in the number of cells immunostained for neuropeptide $\mathrm{Y}$ and the increased intensity of their labeling in the stratum oriens after BDNF treatment. Scale bar, $50 \mu \mathrm{m}$. 

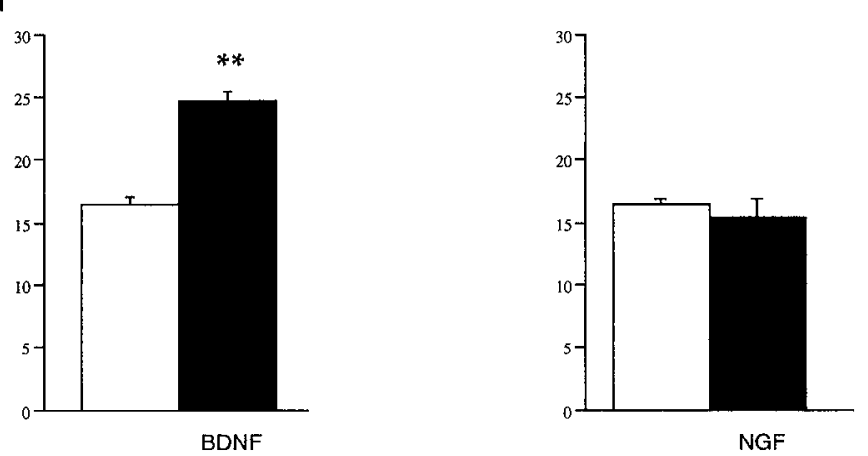

b

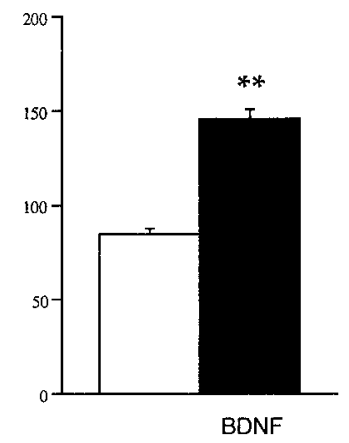

C

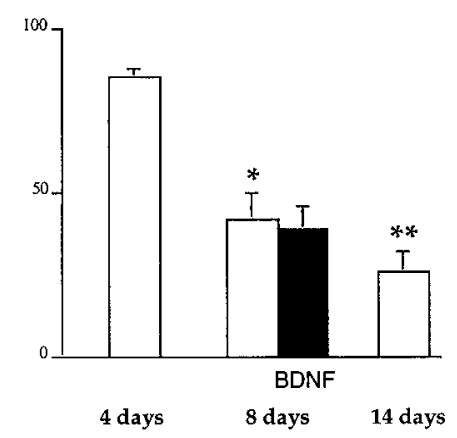

Figure 6. Mean density of calbindin-D-immunoreactive cells $(a)$ and mean number of calretinin-immunoreactive cells $(b-d)$ in the stratum oriens of hippocampal slices $4 \mathrm{~d}$ after explantation. White columns represent the values obtained in control slices, and black columns represent the values obtained in adjacent slices treated with neurotrophins. Student's $t$ test indicates a significant increase in density of calbindin-Dimmunoreactive cells $(a)$ and mean number of calretinin-immunoreactive cells $(b) 4 \mathrm{~d}$ after BDNF treatment $(p<0.01) . c$, A significant decrease in the number of calretinin-immunoreactive cells was observed at $8 \mathrm{~d}(p<$ $0.05)$ and $14 \mathrm{~d}(p<0.01)$ after explantation compared with control slices at $4 \mathrm{~d}$ after explantation. BDNF treatment between 4 and $8 \mathrm{~d}$ after explantation does not prevent a decrease in the number of calretininimmunoreactive ncurons. $d$, A significant incrcase in the number of calretinin-immunoreactive cells was observed after tetrodotoxin and BDNF treatment $(p<0.05)$.

indeed, BDNF increased calretinin or neuropeptide $\mathrm{Y}$ immunostaining (data not shown).

To resolve the issue of whether parvalbumin-containing neurons in the hippocampus express trkB mRNA, a double in situ hybridization-immunohistochemistry procedure was performed. The distribution of trkB transcripts that could be detected by this procedure was similar to the distribution reported by other groups (Altar et al., 1994). A strong and homogeneous labeling was present over all subdivisions of the CA subfield, as well as over the granule cells of the dentate gyrus and scattered neurons in the hilus and the stratum oriens. Parvalbumin immunoreactivity was sufficiently preserved after the in situ hybridization procedure to allow detection of faint to moderately parvalbumin-immunoreactive somata, whereas labeling of processes and terminals was compromised. For most of the parvalbumin-positive neurons, an accumulation of autoradiographic grains over the cell body could be demonstrated (Fig. 7).

In control slices, cells in the stratum oriens were labeled very faintly after neuropeptide $\mathrm{Y}$ immunohistochemistry (Fig. 5C). Neuropeptide $Y$ immunostaining seemed punctiform and thus different from the homogeneous staining of the cytoplasm in labeled cells after immunostaining for calcium-binding proteins. After BDNF treatment, the number of labeled cells and the intensity of their staining increased (Fig. $5 \mathrm{C}$ ).

\section{Effects of BDNF on calretinin-positive Cajal-Retzius cells}

A group of cells surrounding the hippocampal fissure and in the infrapyramidal blade of the dentate gyrus was immunostained for calretinin. However, these cells exhibited lower intensity of staining for calretinin than did cells in the stratum oriens, and they possessed either one or no labeled processes (Fig. 8a). After BDNF treatment, an increase in the intensity of staining of these cells was observed. The increased immunostaining of these cells permitted direct visualization of their morphology, with a single, thick dendritic process emerging from the ovoid cell body (Fig. $8 b$ ). Quantification of the number of these cells exhibiting a labeled process indicated an increase of their number after BDNF treatment (mean \pm SEM: $31 \pm 2$ in control slices, $54 \pm 3$ in BDNF-lreated slices, $p=0.011$ ). These cells are presumed to be the equivalent of the Cajal-Retzius neurons in the cerebral cortex and are transiently present in the hippocampus (von Haebler et al., 1993; Soriano et al., 1994; Del Río et al., 1995). However, the calretinin-positive cells surrounding the hippocampal fissure and in the infrapyramidal blade of the dentate gyrus were observed up to $14 \mathrm{~d}$ after explantation (longest time point studied); it seems that these cells were more resistant to the explantation than were the calretinin-positive interneurons in the stratum oriens. Quantification of the total number of calretinin-immunopositive $\mathrm{Ca}$ jal-Retzius cells surrounding the hippocampal fissure at 4, 8 , and $14 \mathrm{~d}$ after explantation indicated a decrease in their number (mean \pm SEM: $148 \pm 8$ after $4 \mathrm{~d}, 102 \pm 5$ after $8 \mathrm{~d}, 84 \pm$ 4 after $14 \mathrm{~d}$ in culture). A statistically significant difference was found only when comparing the values at 4 and $14 \mathrm{~d}$ ( $p=$ $0.046)$. This decrease in the number of calretinin-positive Cajal-Retzius cells between 4 and $14 \mathrm{~d}$ in culture (43\%) was less than that of calretinin-positive interneurons ( $70 \%$; see above).

Given the responsiveness of hippocampal Cajal-Retzius cells to BDNF, we then used slices from BDNF knock-out mice to determine whether BDNF is a requirement for the survival of these neurons. We first verified that the neurons in these slices were responsive to BDNF. BDNF was potent in inducing $\mathrm{c}$-fos in slices from 8-d-old BDNF knock-out mice, indicating the presence of receptors for BDNF (data not shown). Furthermore, treatment of slices for $4 \mathrm{~d}$ also induced an increased immunostaining for calretinin of the cells surrounding the hippocampal fissure, indicating that Cajal-Retzius cells in these slices were responsive to BDNF (Fig. 9a,b). Quantification of the number of these cells 

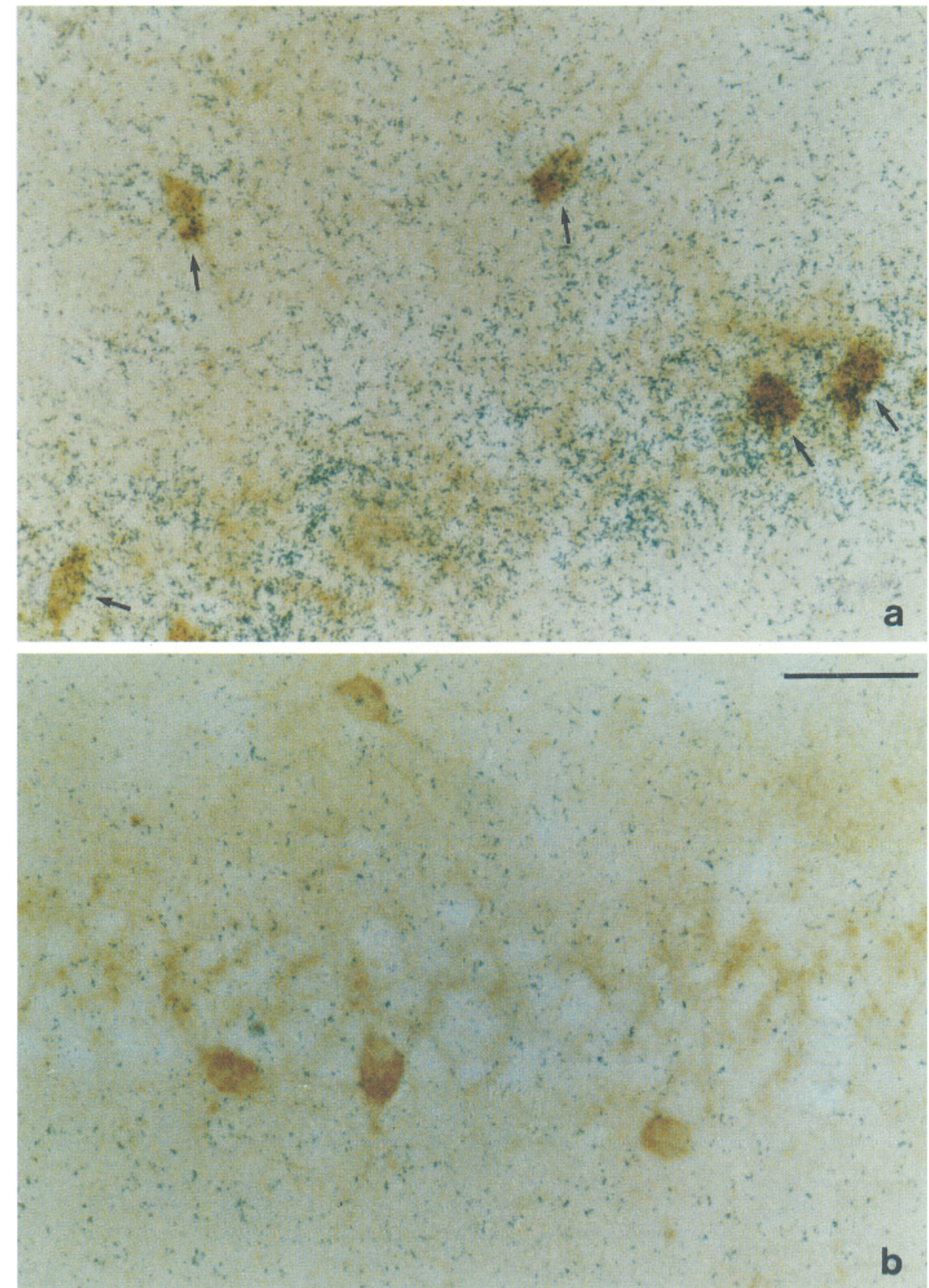

Figure 7. Double-labeling trkB in situ hybridization-parvalbumin immunohistochemistry. $a$, Antisense probe. $b$, Sense probe. Cells labeled by trkB in situ hybridization (black silver grains) are also labeled by parvalbumin immunohistochemistry (brown reaction product; arrows). Scale bar, $50 \mu \mathrm{m}$. exhibiting a labeled process indicated an increase of their number after BDNF treatment (mean \pm SEM: $32 \pm 2$ in control slices, 79 \pm 4 in BDNF-treated slices, $p=0.004$ ). However, numerous calretinin-positive cells exhibiting the same morphology as in the rat slices were also observed in this area in slices from BDNF knock-out mice up to $14 \mathrm{~d}$ after explantation (longest time studied) (Fig. 9c), suggesting that BDNF is not required for their survival.

\section{Effects of BDNF in the presence of tetrodotoxin}

Tetrodotoxin treatment totally abolished the activation of CA1 pyramidal neurons evoked by stimulation of the Schaffer collaterals (Fig. 10).

Tetrodotoxin treatment prevented neither the BDNF-induced increase in the number of calretinin-labeled cells in the stratum oriens (Fig. $6 d$ ) nor the increase in calretinin immunoreactivity of cells surrounding the hippocampal fissure (Fig. 11). The increased neuropeptide $\mathrm{Y}$ immunostaining also was not prevented by tetrodotoxin treatment.

\section{DISCUSSION}

The objective of this study was to reveal the effects of BDNF on the differentiation of hippocampal nonpyramidal neurons using organotypic slice cultures.

Hippocampal neurons in slice cultures from 8-d-old rats respond to BDNF as determined by c-fos induction. Stimulation for $4 \mathrm{~d}$ with BDNF induced an increase of the immunostaining for MAP-2 in nonpyramidal neurons of the stratum oriens. BDNF promotes the elongation of the dendrites of these nonpyramidal cells, as demonstrated by morphometric analysis of biocytinlabeled neurons. Calbindin-D- and calretinin-containing subgroups of nonpyramidal neurons in the stratum oriens were both responsive to BDNF but not to NGF, as shown by an increased 


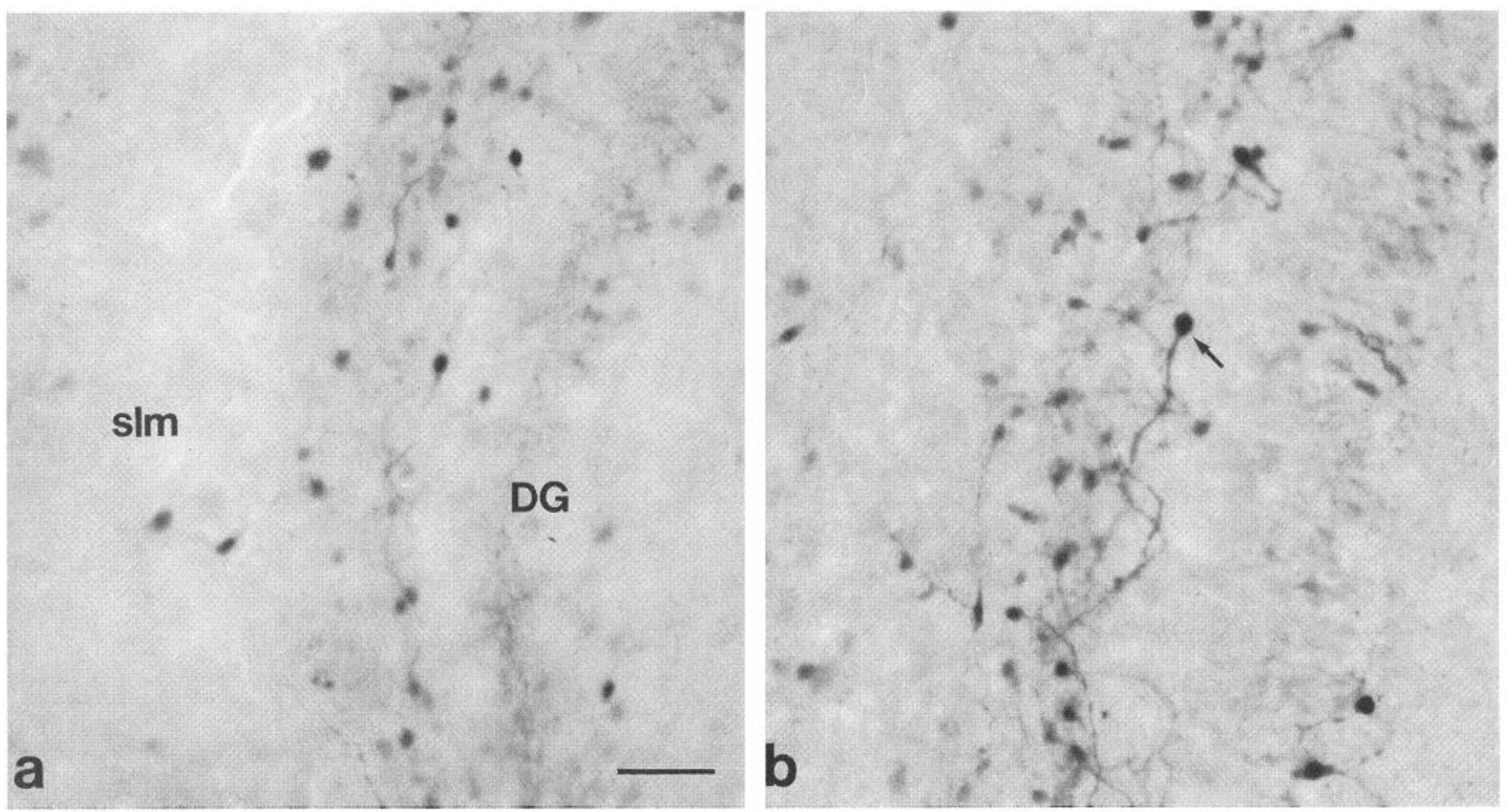

Figure 8. Calretinin immunostaining of hippocampal slices $4 \mathrm{~d}$ after explantation. $a$, Control slice. $b$, BDNF-treated slice. Note the increased immunostaining of cells situated at the border between the stratum lacunosum moleculare $(\mathrm{slm})$ and the dentate gyrus $(D G)$ after BDNF treatment. The labeled cells are monopolar (arrow in $b$ ). Scale bar, $50 \mu \mathrm{m}$.

immunostaining for these calcium-binding proteins. BDNF also increased calretinin immunoreactivity of Cajal-Retzius cells of the hippocampus, but BDNF does not seem to be required for the survival of these neurons because Cajal-Retzius cells were also present in slices from BDNF knock-out mice. The increase in calretinin immunostaining and the BDNF-induced increase in neuropeptide $\mathrm{Y}$ immunostaining were observed in the presence of tetrodotoxin, indicating that these effects of BDNF are independent of neuronal activity.

\section{Specific effects of BDNF on the morphology of stratum oriens nonpyramidal neurons}

BDNF increased the immunostaining for MAP-2 in the stratum oriens after $4 \mathrm{~d}$ of treatment. This effect could have resulted from either an increase in neuronal survival or an increase in MAP-2 content in these cells. Although an effect of BDNF on survival is still unclear, the observation that neurons were labeled more intensely in control slices suggests that at least an increase in MAP-2 content occurred after BDNF. Because a role of MAP-2 in neurite outgrowth and dendritic maintenance has been postulated (Garner et al., 1988; Matus, 1988; Dinsmore and Solomon, 1991; Caceres et al., 1992; Svensson and Aldskogius, 1992), we then searched for an effect of BDNF on the dendritic arborizations of nonpyramidal neurons in the stratum oriens. Morphological analysis after biocytin labeling indicated that the increased MAP-2 content was associated with dendritic elongation in the absence of de novo formation of dendrites or an increase in the number of branching points. This is comparable with the effect of NGF on AChE-positive cells in organotypic slice cultures of the striatum, in which NGF increased the dendritic length without affecting the general branching pattern (Studer et al., 1994). Such a specific effect of BDNF on neuronal morphology was strikingly different from the general increase in the number of dendrites of GABAergic neurons in primary cultures of embryonic hippocampal neurons (S. Marty, unpublished observations). This difference may be attributable to either the different culture conditions or the fact that the slices were prepared from 8-d-old rats, the hippocampal neurons in the stratum oriens being generated prenatally (Bayer, 1980). Between postnatal days 10 and 20, the development of nonpyramidal cells in the stratum oriens is characterized mainly by an increase in dendritic length, paralleled by a decrease in the number of dendritic growth cones (Lang and Frotscher, 1990). Application of BDNF to these neurons at a late stage of their maturation, therefore, seemed only to enhance the ongoing process of dendritic elongation. In vivo, BDNF and trkB mRNA levels increase postnatally in the hippocampus, in parallel with dendritic elongation of nonpyramidal cells (Lang and Frotscher, 1990; Maisonpierre et al., 1990; Masana et al., 1993). Our results suggest that BDNF is involved in the morphological maturation of nonpyramidal neurons in the postnatal hippocampus.

\section{BDNF acts on both the calbindin-D- and the calretinin- containing subgroups of nonpyramidal neurons in the stratum oriens}

The calcium-binding proteins calbindin-D, calretinin, and parvalbumin are expressed by subgroups of hippocampal nonpyramidal cells with little or no overlap (Gulyás et al., 1992; Miettinen et al., 1992; Rogers and Résibois, 1992). We studied whether these subgroups of nonpyramidal cells are responsive to BDNF. Calretinin- and parvalbumin-positive neurons in the stratum oriens and pyramidal cell layer expressed GABA and were considered to be interneurons (Gulyás et al., 1992; Miettinen et al., 1992). In contrast, a high number of calbindin-D-positive neurons 

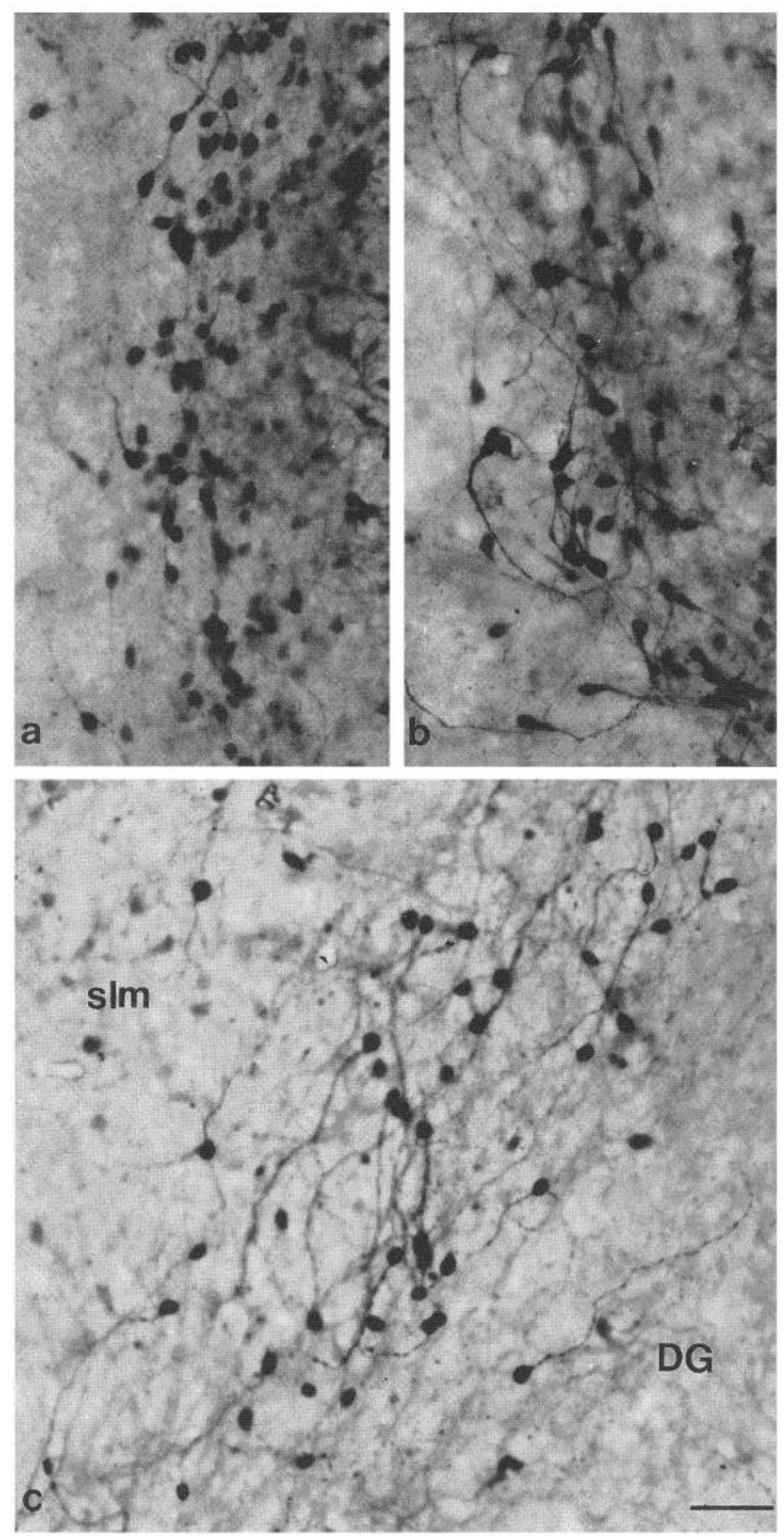

Figure 9. Calretinin immunostaining of hippocampal slices from BDNF knock-out mice. $a$, Control slice. $b$, BDNF-treated slice. Note the increased immunostaining of cells situated at the border between the stratum lacunosum moleculare $(\mathrm{slm})$ and the dentate gyrus $(D G)$ after BDNF treatment, resulting in a much higher number of labeled processes in the BDNF-treated slice. $c$, Labeling $14 \mathrm{~d}$ after explantation. Scale bar, $50 \mu \mathrm{m}$.

in this area were shown to project to the medial septum and were stained only weakly for GABA (Tóth and Freund, 1992). We found that the calbindin-D- and calretinin-positive neurons respond to BDNF, as determined by the increase in their number after treatment. By contrast, we found no effect of BDNF on parvalbumin immunostaining.

The increase in the number of calbindin-D-immunoreactive neurons in the stratum oriens after $4 \mathrm{~d}$ of BDNF treatment may
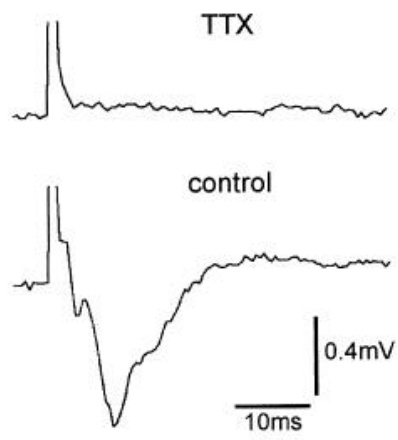

Figure 10. Examples of extracellular recordings in the stratum radiatum of CA1 pyramidal neurons (average of 15 trials). Note that in the tetrodotoxin-treated slice, synaptic field potentials cannot be elicited by stimulation of Schaffer collaterals.

have resulted from either a survival effect of BDNF or an increase in the calcium-binding protein levels within these cells, to an extent that more cells can be detected by an immunohistochemical procedure. The latter seems likely because after BDNF treatment neurons were stained more intensely for calbindin-D than in control slices, which resulted in the appearance of more numerous stained processes.

An effect of BDNF on the content of calretinin in stratum oriens interneurons was more difficult to evaluate because neurons in control slices already exhibited intense labeling. When this neurotrophin was applied between 4 and $8 \mathrm{~d}$ after explantation, it did not prevent the decrease in the number of calretininimmunostained neurons in the stratum oriens during this period. Thus, BDNF either did not exert a survival effect on calretininimmunoreactive neurons in the stratum oriens or was not any more potent in increasing calretinin content.

We propose, therefore, that both the calbindin-D- and the calretinin-containing subgroups of stratum oriens nonpyramidal neurons are responsive to BDNF. This result is consistent with the decrease in immunostaining for calbindin-D observed in BDNF knock-out mice (Jones et al., 1994). In contrast, we were unable to detect an effect of BDNF on parvalbumin-immunoreactive neurons. In primary cultures of hippocampal neurons, BDNF also failed to increase the levels of parvalbumin mRNA (D. Lindholm, unpublished observations). The expression of the trkB receptor by the parvalbumin-positive neurons suggests that levels of parvalbumin, unlike calbindin-D or calretinin, are not regulated by BDNF.

\section{BDNF regulates the calretinin content but not the survival of Cajal-Retzius cells in the postnatal hippocampus}

A subgroup of neurons situated at the level of the hippocampal fissure and in the infrapyramidal blade of the dentate gyrus was identified as Cajal-Retzius cells (von Haebler et al., 1993; Soriano et al., 1994; Del Río et al., 1995). BDNF treatment increased the intensity of their immunostaining for calretinin, indicating that these neurons are responsive to BDNF.

In vivo studies have shown that Cajal-Retzius cells disappear from postnatal day 8 onward, this disappearance occurring in the hippocampus during the second and third postnatal week (Del Río et al., 1993, 1995). Surprisingly, this population of neurons persisted in slices from 8-d-old rats up to $14 \mathrm{~d}$ after explantation. These cells seemed even more resistant to the slice preparation than calretinin-positive interneurons in the stratum oriens, a pop- 

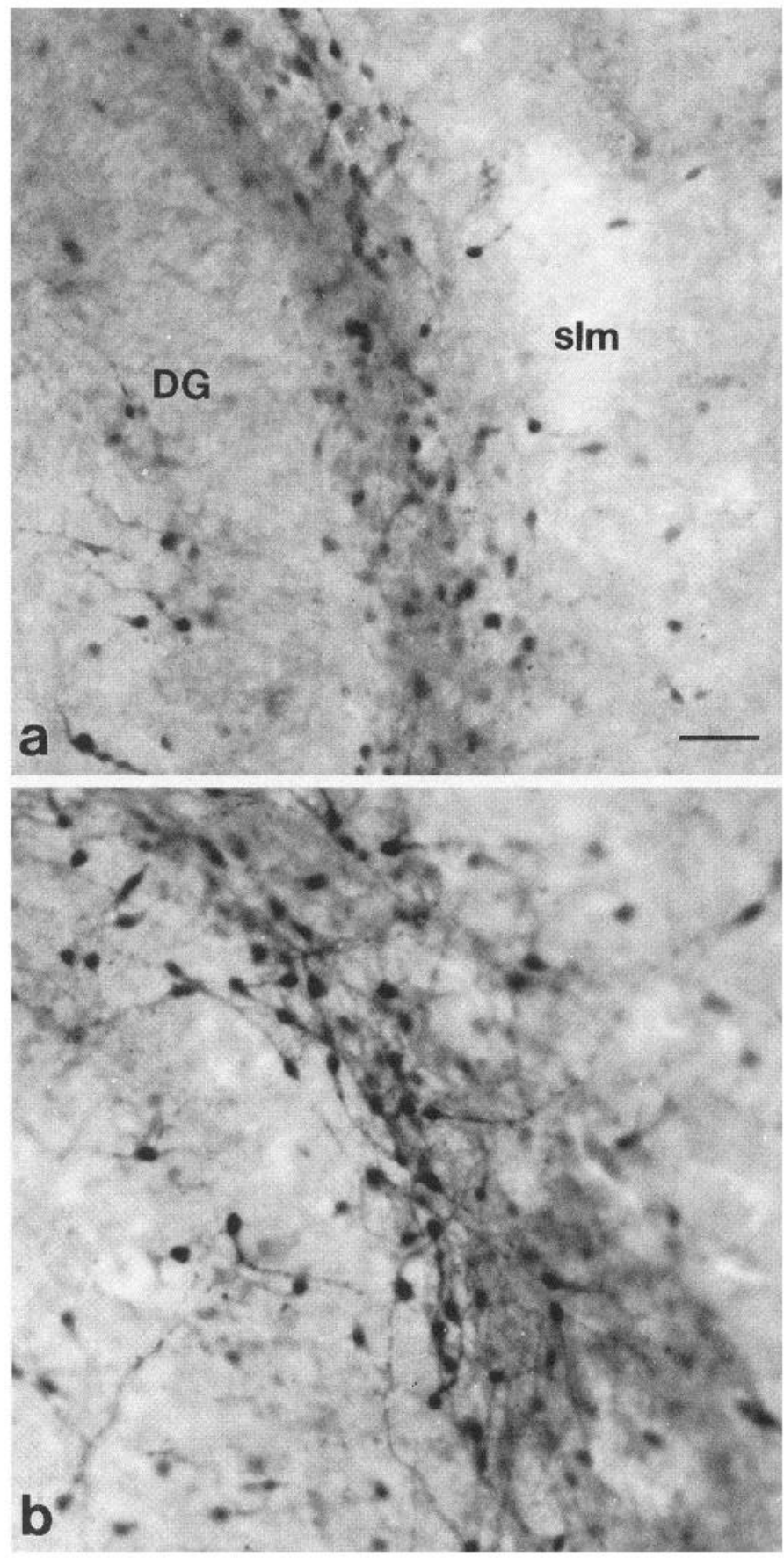

Figure 11. Calretinin immunostaining of hippocampal slices $4 \mathrm{~d}$ after explantation. $a$, Control slice. $b$, Tetrodotoxin- and BDNF-treated slice. Note the increased immunostaining of cells situated at the border between the stratum lacunosum moleculare $(\mathrm{s} / \mathrm{m})$ and the dentate gyrus $(D G)$ after tetrodotoxin and BDNF treatment. Scale bar, $50 \mu \mathrm{m}$.

ulation of neurons that remains throughout adulthood. These data suggest that an afferent influence of extrahippocampal areas is responsible for the disappearance of Cajal-Retzius cells in vivo. However, we found that these neurons are present and that they persisted in slices from BDNF knock-out mice. Although compensatory mechanisms may occur in knock-out mice, this result indicates that BDNF is not an absolute requirement for survival of Cajal-Retzius cells, suggesting that BDNF exerts a differentiation rather than a survival effect on these neurons.

\section{Nonpyramidal neurons as targets for BDNF in the postnatal hippocampus}

Increased calretinin or neuropeptide $\mathrm{Y}$ immunostaining in response to BDNF was obtained in the presence of tetrodotoxin. This indicates that neuronal activity was not necessary for the BDNF effects and suggests that these effects were mediated by the direct interaction of BDNF with its receptor, trkB, on nonpyramidal neurons. The distribution of full-length trkB mRNA in the adult hippocampus shows the presence of highly labeled cells outside of the principal cell layers (Altar et al., 1994) (this study). This contrasts with the distribution of BDNF mRNA in the hippocampus, which is present in the principal cell layers and in the hilus (Ernfors et al., 1990; Castrén et al., 1995). The data suggest that BDNF acts on nonpyramidal cells after being released by their target neurons within the principal cell layers.

Neuronal activity can regulate the level of BDNF mRNA (Zafra et al., 1990, 1991; Berzaghi et al., 1993). In the adult, $\mathrm{GABA}_{\mathrm{A}}$ receptor stimulation reduces BDNF $\mathrm{mRNA}$ (Zafra et al., 1991). In contrast, it was shown recently that $\mathrm{GABA}_{A}$ receptor stimulation increases BDNF mRNA in developing hippocampal neurons (Berninger et al., 1995). This finding suggests that GABAergic neurons regulate their own differentiation via an activity-dependent regulation of BDNF in their target neurons.

\section{REFERENCES}

Altar CA, Siuciak JA, Wright P, Ip NY, Lindsay RM, Wiegand SJ (1994) In situ hybridization of trkB and trkC receptor mRNA in rat forebrain and association with high-affinity binding of ${ }^{125} \mathrm{I}-\mathrm{BDNF},{ }^{125} \mathrm{I}-\mathrm{NT}-4 / 5$ and ${ }^{125}$ I-NT-3. Eur J Neurosci 6:1389-1405.

Barde Y-A (1990) The nerve growth factor family. Prog Growth Factor Res 2:237-248.

Bayer SA (1980) Development of the hippocampal region in the rat. I. Neurogenesis examined with ${ }^{3} \mathrm{H}$-thymidine autoradiography. J Comp Neurol 190:87-114.

Bergmann I, Nitsch R, Frotscher M (1991) Area-specific morphological and neurochemical maturation of non-pyramidal neurons in the rat hippocampus as revealed by parvalbumin immunocytochemistry. Anat Embryol (Berl) 184:403-409.

Berninger B, Marty S, Zafra F, Berzaghi M, Thoenen H, Lindholm D (1995) GABAergic stimulation switches from enhancing to repressing BDNF expression in rat hippocampal neurons during maturation in vitro. Development 121:2327-2335.

Berzaghi MP, Cooper J, Castrén E, Zafra F, Sofroniew M, Thoenen H, Lindholm D (1993) Cholinergic regulation of brain-derived neurotrophic factor (BDNF) but not neurotrophin-3 (NT-3) mRNA levels in the developing rat hippocampus. J Neurosci 13:3818-3826.

Berzaghi MP, Gutierrez R, Heinemann U, Lindholm D, Thoenen H (1995) Neurotrophins induce acute transmitter-mediated changes in brain electrical activity. Soc Neurosci Abstr 21:545.

Caceres A, Mautino J, Kosik KS (1992) Suppression of MAP2 in cultured cerebellar macroneurons inhibits minor neurite formation. Neuron 9:607-618.

Castrén E, Thoenen H, Lindholm D (1995) Brain-derived neurotrophic factor messenger RNA is expressed in the septum, hypothalamus and in adrenergic brain stem nuclei of adult rat brain and is increased by osmotic stimulation in the paraventricular nucleus. Neuroscience 64:71-80.

Collazo D, Takahashi H, McKay RDG (1992) Cellular targets and trophic functions of neurotrophin-3 in the developing rat hippocampus. Neuron 9:643-656.

Croll SD, Wiegand SJ, Anderson KD, Lindsay RM, Nawa H (1994) Regulation of neuropeptides in adult rat forebrain by the neurotrophins BDNF and NGF. Eur J Neurosci 6:1343-1353.

Davies AM (1994) The role of neurotrophins in the developing nervous system. J Neurobiol 25:1334-1348.

Del Río JA, Martínez A, Fonseca M, Auladell C, Soriano E (1995) Glutamate-like immunoreactivity and fate of Cajal-Retzius cells in the murine cortex as identified with Calretinin antibody. Cereb Cortex 5:13-21. 
Del Rio JA, Rocamora N, Soriano E (1993) The organization of the embryonic and early postnatal murine hippocampus: times of generation and fate of neurons in the subplate and marginal zone. Eur $\mathrm{J}$ Neurosci [Suppl] 6:151.

Dinsmore JH, Solomon F (1991) Inhibition of MAP-2 expression affects both morphological and cell division phenotypes of neuronal differentiation. Cell 64:817-826.

Ernfors P, Lee K-F, Jaenisch R (1994) Mice lacking brain-derived neurotrophic factor develop with sensory deficits. Nature 368:147-150.

Ernfors P, Wetmore C, Olson L, Persson H (1990) Identification of cells in rat brain and peripheral tissues expressing mRNA for members of the nerve growth factor family. Neuron 5:511-526.

Garner CC, Tucker RP, Matus A (1988) Selective localization of messenger RNA for cytoskeletal protein MAP2 in dendrites. Nature 336:674-677.

Götz R, Köster R, Winkler C, Raulf F, Lottspeich F, Schartl M, Thoenen $\mathrm{H}$ (1994) Neurotrophin-6 is a new member of the neurotrophin family. Nature 372:266-269.

Gulyás AI, Miettinen R, Jacobowitz DM, Freund TF (1992) Calretinin is present in non-pyramidal cells of the rat hippocampus. I. A new type of neuron specifically associated with the mossy fibre system. Neuroscience 48:1-27.

Hasty P, Bradley A (1993) Gene targeting vectors for mammalian cells. In: Gene targeting: a practical approach (Joyner AL, ed), pp 1-32. New York: Oxford UP.

I Iofer M, Pagliusi SR, Hohn A, Leibrock J, Barde Y-A (1990) Regional distribution of brain-derived neurotrophic factor mRNA in the adult mouse brain. EMBO J 9:2459-2464.

Ip NY, Li Y, Yancopoulos GD, Lindsay RM (1993) Cultured hippocampal neurons show responses to BDNF, NT-3, and NT-4, but not NGF. J Neurosci 13:3394-3405.

Jones KR, Farinas I, Backus C, Reichardt LF (1994) Targeted disruption of the BDNF gene perturbs brain and sensory neuron development but not motor neuron development. Cell 76:989-999.

Kang H, Schuman EM (1995) Long-lasting neurotrophin-induced enhancement of synaptic transmission in the adult hippocampus. Science 267:1658-1662.

Korte M, Carroll P, Wolf E, Brem G, Thoenen H, Bonhoeffer T (1995) Hippocampal long-term potentiation is impaired in BDNF-deficient mice. Proc Natl Acad Sci USA 92:8856-8860.

Lang U, Frotscher M (1990) Postnatal development of nonpyramidal neurons in the rat hippocampus (areas $\mathrm{CA} 1$ and $\mathrm{CA} 3$ ): a combined Golgi/electron microscope study. Anat Embryol 181:533-545.

LaVail JH, Wolf MK (1973) Postnatal development of the mouse dentate gyrus in organotypic cultures of the hippocampal formation. Am J Anat 137:47-66.

Lessmann V, Gottmann K, Heumann R (1994) BDNF and NT-4/5 enhance glutamatergic synaptic transmission in cultured hippocampal neurones. NeuroReport 6:21-35.

Lindsay RM (1993) Brain-derived neurotrophic factor: an NGF-related neurotrophin. In: Neurotrophic factors (Loughlin SE, Fallon JH, eds), pp 257-284. San Diego: Academic.

Maisonpierre PC, Belluscio L, Friedman B, Alderson RF, Wiegand SJ, Furth ME, Lindsay RM, Yancopoulos GD (1990) NT-3, BDNF, and NGF in the developing rat nervous system: parallel as well as reciprocal patterns of expression. Neuron 5:501-509.

Marsh HN, Scholz WK, Lamballe F, Klein R, Nanduri V, Barbacid M, Palfrey HC (1993) Signal transduction events mediated by the BDNF receptor gp 145 trkB in primary hippocampal pyramidal cell culture. J Neurosci 13:4281-4292.

Masana Y, Wanaka A, Kato H, Asai T, Tohyama M (1993) Localization of trkB mRNA in postnatal brain development. J Neurosci Res 35:468-479.

Matus A (1988) Microtubule-associated proteins: their potential role in determining neuronal morphology. Annu Rev Neurosci 1:29-44.

McDonald AJ (1992) Neuroanatomical labeling with biocytin: a review. NeuroReport 3:821-827.

Miettinen R, Gulyás AI, Baimbridge KG, Jacobowitz DM, Freund TF (1992) Calretinin is present in non-pyramidal cells of the rat hippocampus. II. Co-existence with other calcium binding proteins and GABA. Neuroscience 48:29-43.

Nawa H, Pelleymounter MA, Carnahan J (1994) Intraventricular administration of BDNF increases neuropeptide expression in newborn rat brain. J Neurosci 14:3751-3765.

Nitsch R, Bergmann I, Küppers K, Mueller G, Frotscher M (1990) Late appearance of parvalbumin-immunoreactivity in the development of GABAergic neurons in the rat hippocampus. Neurosci Lett 118:147-150.

Ohsawa F, Widmer HR, Knusel B, Denton TL, Hefti F (1993) Response of embryonic rat hippocampal neurons in culture to neurotrophin-3, brain-derived neurotrophic factor and basic fibroblast growth factor. Neuroscience 57:67-77.

Rogers JH, Résibois A (1992) Calretinin and calbindin-D28k in rat brain: patterns of partial co-localization. Neuroscience 51:843-865.

Snider WD (1994) Functions of the neurotrophins during nervous system development: what the knockouts are teaching us. Cell 77:627-638.

Soriano E, Del Rio JA, Martinez A, Superr H (1994) Organization of the embryonic and early postnatal murine hippocampus. I. Immunocytochemical characterization of neuronal populations in the subplate and marginal zone. J Comp Neurol 342:571-595.

Stoppini L, Buchs P-A, Muller D (1991) A simple method for organotypic cultures of nervous tissue. J Neurosci Methods 37:173-182.

Studer L, Spenger C, Luthman J, Seiler RW (1994) NGF increases neuritic complexity of cholinergic interneurons in organotypic cultures of neonatal rat striatum. J Comp Neurol 340:281-296.

Suda K, Barde YA, Thoenen H (1978) Nerve growth factor in mouse and rat serum: correlation between bioassay and radioimmunoassay determinations. Proc Natl Acad Sci USA 75:4042-4046.

Svensson M, Aldskogius H (1992) The effect of axon injury on microtubule-associated proteins MAP2, 3 and 5 in the hypoglossal nucleus of the adult rat. J Neurocytol $21: 222-231$.

Tóth K, Freund TF (1992) Calbindin D28k-containing nonpyramidal cells in the rat hippocampus: their immunoreactivity for GABA and projection to the medial septum. Neuroscience 49:793-805.

von Haebler D, Stabel J, Draguhn A, Heinemann U (1993) Properties of horizontal cells transiently appearing in the rat dentate gyrus during ontogenesis. Exp Brain Res 94:33-42.

Zafra F, Castrén E, Thoenen H, Lindholm D (1991) Interplay between glutamate and gamma-aminobutyric acid transmitter systems in the physiological regulation of brain-derived neurotrophic factor and nerve growth factor synthesis in hippocampal neurons. Proc Natl Acad Sci USA 88:10037-10041.

Zafra F, Hengerer B, Leibrock J, Thoenen H, Lindholm D (1990) Activity dependent regulation of BDNF and NGF mRNAs in the rat hippocampus is mediated by non-NMDA glutamate receptors. EMBO J 9:3545-3550. 